\title{
Accumulation of Heavy Metals in Tissues of Long Tail Tuna from Karachi Fish Harbour, Pakistan
}

\author{
Quratulan Ahmed \\ The Marine Reference Collection and Resources Centre, University of Karachi \\ Karachi, 75270, Pakistan \\ Tel: 92-345-298-3586_E-mail: quratulanahmed_ku@yahoo.com
}

Levent Bat

Department of Hydrobiology, Fisheries Faculty, Sinop University

TR57000, Sinop, Turkey

Tel: 90-368-287-6254 E-mail: leventbat@gmail.com

\author{
Farzana Yousuf \\ Department of Zoology, University of Karachi \\ Karachi, 75270, Pakistan
}

Tel: 92-345-298-3586_E-mail: Farzanaseth@yahoo.com

Received: November 20, 2014 Accepted: December 10, 2014 Published: January 1, 2015

doi:10.5296/ast.v3i1.6814 URL: http://dx.doi.org/10.5296/ast.v3i1.6814

\begin{abstract}
The present study was conducted to investigate the contamination of $\mathrm{Fe}, \mathrm{Mn}, \mathrm{Cu}, \mathrm{Zn}, \mathrm{Ni}, \mathrm{Pb}$, $\mathrm{Cd}$, and $\mathrm{Cr}$ in the tissues of commercially important fish Thunnus tonggol and to evaluate risks to human health associated with seafood consumption. The results from this study showed that the concentrations of all metals measured except $\mathrm{Cr}$ were relatively high in the liver compared to the muscle, gills and gonads. High concentrations of $\mathrm{Cr}$ were present in the kidneys. Fe had the highest concentration compared with other metals tested in all tissues of followed by $\mathrm{Cu}$ and $\mathrm{Zn}$. The highest mean concentration $(\mu \mathrm{g} / \mathrm{g})$ of $\mathrm{Fe} 36.43 \pm 11.41, \mathrm{Mn}$ $1.29 \pm 1.08, \mathrm{Cu} 23.35 \pm 11.47, \mathrm{Zn} 3.89 \pm 2.23$, Ni $0.35 \pm 0.12$, Pb 0.27 $\pm 0.12, \mathrm{Cd} 0.71 \pm 0.13$ and $\mathrm{Cr}$ $0.35 \pm 0.20$ were recorded in the edible muscle tissues of the fish. Overall, the findings from
\end{abstract}


the present study revealed that all metals except $\mathrm{Cu}$ and $\mathrm{Cd}$ concentrations in the muscle tissues were lower than the maximum permissible limit as recommended by the international regulations. However, the estimated the Provisional Tolerable Weekly Intake (PTWI) of Cu is below the established PTWI. The data indicate that the examined fish were polluted with $\mathrm{Cd}$. It was also found that levels of the metals in other tissues in some samples were higher than the recommended concentrations. However, consumers do not consume the liver, kidney, gills and gonads.

Keywords: Thunnus tonggol, Heavy metals, Karachi Fish Harbour, Pakistan 


\section{Introduction}

Fish have an important place in the diet of Pakistan and are a good source of digestible protein vitamins, minerals and polyunsaturated fatty acids (PUFA). However, fish are also source of metals. Some of the metals found in the fish might be essential as they play important role in biological system of the fish as well as in human being, some of them may also be toxic as might cause a serious damage in human health even in trace amount at a certain limit. The term of heavy metals has been replaced in years by a classification scheme that considers their chemistry rather than relative density (Nieboer \& Richardson, 1980). Separation of some essential and non-essential metal ions of importance as pollutants into class A (oxygen-seeking) including $\mathrm{Ca}, \mathrm{Mg}, \mathrm{Mn}, \mathrm{K}, \mathrm{Sr}$, $\mathrm{Na}$, class $\mathrm{B}$ (sulphur or nitrogen-seeking) including $\mathrm{Zn}, \mathrm{Pb}, \mathrm{Fe}, \mathrm{Cr}, \mathrm{Co}, \mathrm{Ni}, \mathrm{As}, \mathrm{V}$ and borderline elements including $\mathrm{Cd}, \mathrm{Cu}, \mathrm{Hg}, \mathrm{Ag}$ based on the classification scheme of Nieboer and Richardson (1980). As a results fish may accumulate large amounts of some metals from the water and from their food and then deposit them in the tissue. Therefore it is important to determine the concentration of heavy metals in commercial fish in order to evaluate the possible risk of fish consumption to human health (Pérez Cid et al., 2001). The common heavy metals that are found in fish include $\mathrm{Cu}, \mathrm{Fe}, \mathrm{Zn}, \mathrm{Mn}, \mathrm{Hg}, \mathrm{Pb}$ and $\mathrm{Cd}$ (Connell, 1984). Evidence from the literature strongly indicates heavy metal toxicity in the marine environment as a majors concern to human health. Industrial and agricultural activities were reported as the likely source of the accumulation of pollutants in the aquatic environment including the sea (Tarra-Wahlberg et al., 2001; Akif et al., 2002).

Tuna, as a predator, is able to concentrate large amount of heavy metals via food chain. Some of them are used for biomonitoring of environmental contamination (Enomoto \& Uchida, 1973; Schmitt \& Brumbaugh, 1990). Numerous human health concerns have been linked to the injection of heavy metals. For example, the most common toxic effects of cadmium in humans is renal failure, accumulation in bone matter resulting in calcium loss and also malfunctioning of peripheral and central nervous system (Schroeder et al.,1965). Large fish such as Swordfish (Xiphias gladius), Yellowfin Tunas (Tunnus al-bacares), Skipjacks (Katsuwonus pelamis) and Common Dolfinfish (Coryphaena hippurus), which are at the top of marine food webs, are particularly exposed to high levels of trace elements through their food (Bryan, 1979). These pelagic organisms are high performance fish with very high metabolic rates, and consequently high food intake rates, a property that accentuates the exposure to heavy metals (Kojadinovic et al., 2007). Accumulations of heavy metals were generally found to be species specific and may be related to their feeding habits and the bio-concentration capacity of each species (Bat et al., 2013). Topping (1973) suggested that mainly plankton feeding fish contain much higher concentrations of some heavy metals than bottom feeding fish. Consequently, fish are widely used as biomonitor for assessing heavy metal contamination level of aquatic environment and the health state of marine ecosystems.

The objective of the present study is to provide information on the $\mathrm{Fe}, \mathrm{Mn}, \mathrm{Cu}, \mathrm{Zn}, \mathrm{Ni}, \mathrm{Pb}$, $\mathrm{Cd}$ and $\mathrm{Cr}$ levels in the muscle, liver, kidney, gills and gonads tissues of Thunnus tonggol. The fish for the metal determinations were collected from Karachi Fish Harbour, Pakistan 


\section{Macrothink}

Aquatic Science and Technology

ISSN 2168-9148

2015, Vol. 3, No. 1

between August 2006 and December 2011. It is also attempted to compare the measured values with international standards for food and human health.

\section{Material and Method}

Fish samples (T. tonggol) were collected in August, 2006 to December, 2011 from the fish landing Centre, at Fish Harbour West Wharf Karachi, Pakistan, located in the north eastern border of the Arabia Sea, lying between $24^{\circ} 50^{\prime} 54.71^{\prime \prime} \mathrm{N}$ and $66^{\circ} 58^{\prime} 38.68^{\prime \prime} \mathrm{E}$ (Figure 1). Collected samples were immediately transported to the laboratory in ice boxes and allowed to thaw and rinsed in distilled water. Total lengths $(\mathrm{cm})$ and weights $(\mathrm{g})$ of fish were determined (Table 1; Figure 2). The fishes were dissected. To avoid contamination problems the glassware and sample containers were pre-cleaned by soaking in a $10 \% \mathrm{HNO} 3$ solution more than 24 hours, and then rinsed at least three times with bi-distilled water before use.

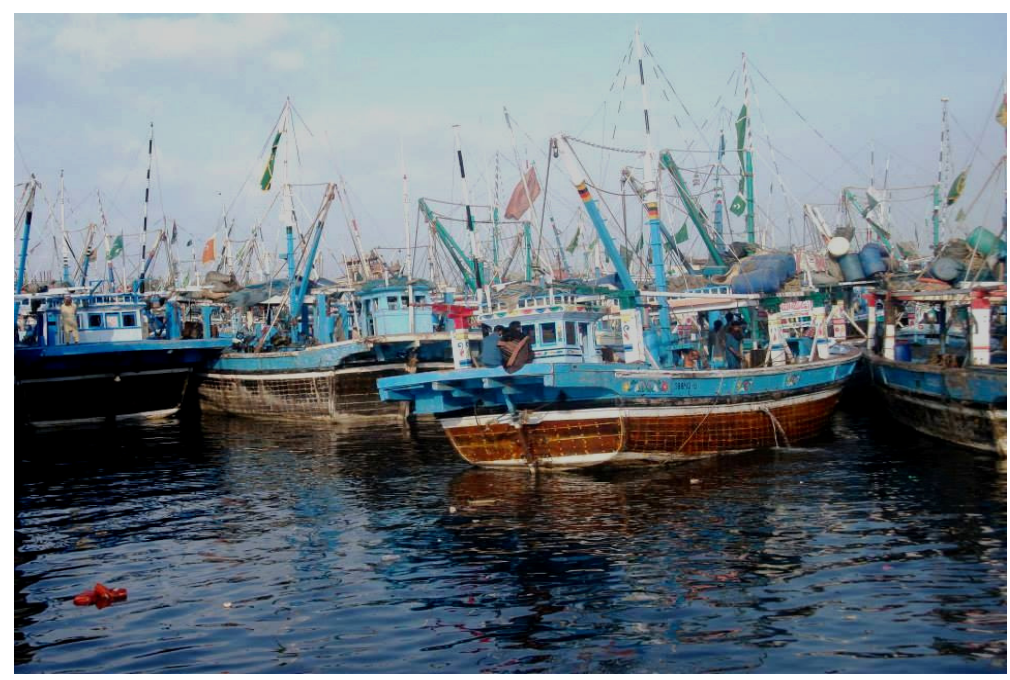

Figure 1. Fish Harbour of Karachi, Pakistan

Table 1. Mean length and weight of fish during years 2006-2011

\begin{tabular}{lccc}
\hline Years & $\mathrm{n}$ & $\begin{array}{c}\text { Length }(\mathrm{cm}) \\
\text { Mean } \pm \text { SD } \\
(\text { Min-Max })\end{array}$ & $\begin{array}{c}\text { Weight (g) } \\
\text { Mean } \pm \text { SD } \\
(\text { Min-Max })\end{array}$ \\
\hline $2006-2007$ & 52 & $\begin{array}{c}62.0 \pm 2.23 \\
(59-64.8)\end{array}$ & $\begin{array}{c}2500 \pm 222.92 \\
(2200-2900)\end{array}$ \\
\hline $2007-2008$ & 63 & $\begin{array}{c}62.0 \pm 2.11 \\
(58-66)\end{array}$ & $\begin{array}{c}2200 \pm 248.84 \\
(2200-3100)\end{array}$ \\
\hline $2008-2009$ & 65 & $\begin{array}{c}60.0 \pm 4.44 \\
(48-68)\end{array}$ & $\begin{array}{c}2400 \pm 495.95 \\
(1200-3200)\end{array}$ \\
\hline $2009-2010$ & 62 & $\begin{array}{c}61.0 \pm 1.70 \\
(58-66)\end{array}$ & $\begin{array}{c}2400 \pm 317.08 \\
(1800-3100)\end{array}$ \\
\hline $2010-2011$ & 58 & $\begin{array}{c}61.0 \pm 3.61 \\
(52-72)\end{array}$ & $\begin{array}{c}2600 \pm 586.64 \\
(1400-3900)\end{array}$ \\
\hline
\end{tabular}




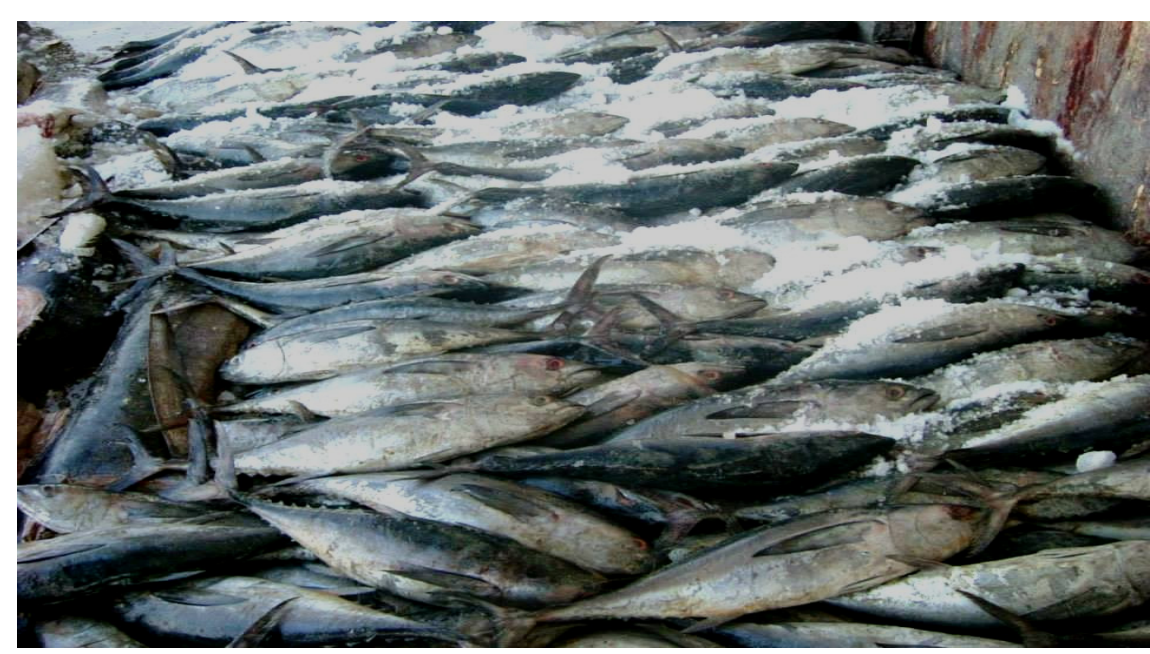

Figure 2. Collection of Thunnus tonggol at Fish Harbour

The muscle, liver, kidney, gills and gonads tissues of the fish were prepared for analysis according to the method described by Bernhard (1976). Approximately $5 \mathrm{~g}$ dorsal muscles, entire liver, 2 rakers of gills, entire kidney, and entire gonads were prepared separately from individual fish which were then cut into small pieces and homogenized. The samples were then placed in a muffle furnace and the temperature was gradually increased to $500 \mathrm{oC}$ over a period of 3 hours to avoid a loss of material due to sudden combustion. The samples remained in the muffle furnace for 72 hours until they had been reduced to a grey to white ash. The ashes were dissolved with 10 millilitres of $0.1 \mathrm{M} \mathrm{HCl}$ according to the method of Gutierrez et al. (1978).

As a means of comparison, three working standards ( $2 \mathrm{ppm}, 4 \mathrm{ppm}$ and $6 \mathrm{ppm}$ ) were prepared from $1000 \mathrm{ppm}$ stock solution. The samples were analyzed for heavy metals using the equipment Analyst 700 with programme win lab 32 software.

The results of the research were processed using statistical methods (ANOVA). The data transformations allowed for adjusting of all the zero values in the analytical results prior to the ANOVA test (Zar, 1984).

\section{Results and Discussion}

The seasonal variations of heavy metals in T. tonggol collected from Fish Harbour Karachi were studied. The mean concentration of heavy metals ( $\mathrm{Fe}, \mathrm{Mn}, \mathrm{Cu}, \mathrm{Zn}, \mathrm{Ni}, \mathrm{Pb}, \mathrm{Cd}$ and $\mathrm{Cr}$ ) determined in the muscle, liver, kidney, gills and gonads tissues of T. tonggol are given Table 2. The levels of metals ranged from $6.96 \pm 3.67 \mu \mathrm{g} / \mathrm{g}$ in kidney to $553.92 \pm 169.45 \mu \mathrm{g} / \mathrm{g}$ in liver for $\mathrm{Fe}, 0.40 \pm 0.23 \mu \mathrm{g} / \mathrm{g}$ in kidney to $6.47 \pm 2.47 \mu \mathrm{g} / \mathrm{g}$ in liver for Mn, $3.16 \pm 1.37 \mu \mathrm{g} / \mathrm{g}$ in gonads to $63.36 \pm 19.51 \mu \mathrm{g} / \mathrm{g}$ in liver for $\mathrm{Cu}, 1.27 \pm 20.65 \mu \mathrm{g} / \mathrm{g}$ in gills to $19.72 \pm 9.15 \mu \mathrm{g} / \mathrm{g}$ in liver for $\mathrm{Zn}, 0.14 \pm 0.10 \mu \mathrm{g} / \mathrm{g}$ in kidney to $1.46 \pm 0.56 \mu \mathrm{g} / \mathrm{g}$ in liver for $\mathrm{Ni}, 0.17 \pm 0.08 \mu \mathrm{g} / \mathrm{g}$ in gonads to $2.63 \pm 0.62 \mu \mathrm{g} / \mathrm{g}$ in liver for $\mathrm{Pb}, 0.19 \pm 0.12 \mu \mathrm{g} / \mathrm{g}$ in gills to $2.7 \pm 1.05 \mu \mathrm{g} / \mathrm{g}$ in liver for $\mathrm{Cd}$ and $0.16 \pm 0.14 \mu \mathrm{g} / \mathrm{g}$ in gonads to $1.5 \pm 0.78 \mu \mathrm{g} / \mathrm{g}$ in kidney for $\mathrm{Cr}$ at Fish Harbour Karachi in $\mathrm{T}$. tonggol. Liver concentrations of all metals except $\mathrm{Cr}$, were higher than other tissues tested. The statistical results presented in Table 3 indicate that there is a considerable greater 
accumulation of the metals in liver than in muscle tissues $(\mathrm{P}<0.05)$ and that there was a statistically significant difference between the concentrations of the metals among years.

Table 2. Mean concentration of metals with standard deviation $(\mu \mathrm{g} / \mathrm{g}$ dry wt.) in different organs of fish collected from Karachi fish harbour during years (2006-2011)

\begin{tabular}{|c|c|c|c|c|c|c|c|}
\hline Metals & Years & $\mathrm{n}$ & $\begin{array}{c}\text { Muscles } \\
(\text { Mean } \pm \text { SD })\end{array}$ & $\begin{array}{c}\text { Liver } \\
(\mathrm{Mean} \pm \mathrm{SD})\end{array}$ & $\begin{array}{c}\text { Kidney } \\
(\text { Mean } \pm \mathrm{SD})\end{array}$ & $\begin{array}{c}\text { Gills } \\
(\text { Mean } \pm \mathrm{SD})\end{array}$ & $\begin{array}{c}\text { Gonads } \\
(\text { Mean } \pm S D)\end{array}$ \\
\hline \multirow{5}{*}{$\mathrm{Fe}$} & $2006-2007$ & 52 & $26.11 \pm 10.48$ & $553.92 \pm 169.45$ & $6.96 \pm 3.67$ & $15.06 \pm 7.91$ & $12.34 \pm 3.51$ \\
\hline & $2007-2008$ & 63 & $24.7 \pm 11.51$ & $437.65 \pm 178.80$ & $8.73 \pm 5.02$ & $16.41 \pm 8.19$ & $14.52 \pm 3.81$ \\
\hline & 2008-2009 & 65 & $25.65 \pm 11.20$ & $433.14 \pm 134.56$ & $12.74 \pm 9.52$ & $19.87 \pm 8.33$ & $14.56 \pm 3.92$ \\
\hline & 2009-2010 & 62 & $35.72 \pm 12.44$ & $427.65 \pm 113.78$ & $14.58 \pm 5.84$ & $20.10 \pm 9.74$ & $16.52 \pm 5.45$ \\
\hline & 2010-2011 & 58 & $36.43 \pm 11.41$ & $464.36 \pm 154.98$ & $16.32 \pm 8.68$ & $25.51 \pm 12.37$ & $24.14 \pm 8.40$ \\
\hline \multirow{5}{*}{$\mathrm{Mn}$} & $2006-2007$ & 52 & $0.50 \pm 0.30$ & $3.87 \pm 2.59$ & $0.40 \pm 0.23$ & $1.46 \pm 1.12$ & $0.46 \pm 0.25$ \\
\hline & $2007-2008$ & 63 & $0.52 \pm 0.32$ & $4.64 \pm 2.37$ & $0.51 \pm 0.25$ & $1.84 \pm 1.05$ & $0.41 \pm 0.33$ \\
\hline & 2008-2009 & 65 & $1.29 \pm 1.08$ & $5.54 \pm 2.74$ & $0.49 \pm 0.24$ & $1.98 \pm 0.93$ & $0.58 \pm 0.39$ \\
\hline & 2009-2010 & 62 & $0.63 \pm 0.55$ & $6.47 \pm 2.47$ & $0.59 \pm 0.42$ & $2.23 \pm 1.45$ & $0.63 \pm 0.44$ \\
\hline & 2010-2011 & 58 & $0.44 \pm 0.23$ & $6.35 \pm 3.11$ & $0.50 \pm 0.32$ & $2.16 \pm 1.75$ & $0.46 \pm 0.28$ \\
\hline \multirow{5}{*}{$\mathrm{Cu}$} & $2006-2007$ & 52 & $16.21 \pm 6.18$ & $63.36 \pm 19.51$ & $6.81 \pm 3.40$ & $3.63 \pm 1.81$ & $3.16 \pm 1.37$ \\
\hline & $2007-2008$ & 63 & $14.25 \pm 7.41$ & $56.21 \pm 18.10$ & $5.86 \pm 3.21$ & $3.50 \pm 2.80$ & $4.12 \pm 1.38$ \\
\hline & 2008-2009 & 65 & $20.44 \pm 8.23$ & $51.59 \pm 17.03$ & $10.21 \pm 3.69$ & $6.43 \pm 2.66$ & $4.41 \pm 1.26$ \\
\hline & $2009-2010$ & 62 & $23.35 \pm 11.47$ & $41.46 \pm 24.53$ & $5.58 \pm 2.87$ & $5.52 \pm 2.40$ & $5.08 \pm 1.50$ \\
\hline & 2010-2011 & 58 & $23.22 \pm 11.07$ & $53.25 \pm 14.54$ & $5.36 \pm 3.57$ & $6.55 \pm 2.38$ & $4.31 \pm 1.32$ \\
\hline \multirow{5}{*}{$\mathrm{Zn}$} & $2006-2007$ & 52 & $2.73 \pm 1.83$ & $10.01 \pm 4.20$ & $3.46 \pm 2.03$ & $1.27 \pm 0.65$ & $1.49 \pm 1.29$ \\
\hline & $2007-2008$ & 63 & $3.01 \pm 1.94$ & $15.63 \pm 11.98$ & $3.69 \pm 1.06$ & $1.62 \pm 1.23$ & $1.75 \pm 1.09$ \\
\hline & 2008-2009 & 65 & $2.65 \pm 1.91$ & $17.73 \pm 8.89$ & $4.09 \pm 1.79$ & $3.37 \pm 2.10$ & $3.26 \pm 1.66$ \\
\hline & 2009-2010 & 62 & $1.93 \pm 1.21$ & $16.78 \pm 9.80$ & $3.46 \pm 2.45$ & $2.63 \pm 1.93$ & $4.45 \pm 1.32$ \\
\hline & 2010-2011 & 58 & $3.89 \pm 2.23$ & $19.72 \pm 9.15$ & $4.13 \pm 2.38$ & $2.20 \pm 1.43$ & $4.98 \pm 1.89$ \\
\hline \multirow{5}{*}{$\mathrm{Ni}$} & $2006-2007$ & 52 & $0.18 \pm 0.12$ & $0.54 \pm 0.12$ & $0.14 \pm 0.10$ & $0.19 \pm 0.06$ & $0.16 \pm 0.12$ \\
\hline & $2007-2008$ & 63 & $0.22 \pm 0.16$ & $0.63 \pm 0.43$ & $0.33 \pm 0.17$ & $0.26 \pm 0.10$ & $0.33 \pm 0.12$ \\
\hline & 2008-2009 & 65 & $0.21 \pm 0.15$ & $1.26 \pm 0.38$ & $0.51 \pm 0.19$ & $0.42 \pm 0.22$ & $0.33 \pm 0.14$ \\
\hline & 2009-2010 & 62 & $0.31 \pm 0.17$ & $1.46 \pm 0.56$ & $0.41 \pm 0.14$ & $0.62 \pm 0.48$ & $0.44 \pm 0.21$ \\
\hline & 2010-2011 & 58 & $0.35 \pm 0.12$ & $0.93 \pm 0.53$ & $0.79 \pm 0.19$ & $1.26 \pm 0.35$ & $0.74 \pm 0.29$ \\
\hline \multirow{5}{*}{$\mathrm{Pb}$} & $2006-2007$ & 52 & $0.18 \pm 0.10$ & $0.58 \pm 0.21$ & $0.18 \pm 0.04$ & $0.19 \pm 0.12$ & $0.18 \pm 0.06$ \\
\hline & $2007-2008$ & 63 & $0.23 \pm 0.14$ & $0.52 \pm 0.18$ & $0.35 \pm 0.17$ & $0.32 \pm 0.18$ & $0.17 \pm 0.08$ \\
\hline & 2008-2009 & 65 & $0.19 \pm 0.11$ & $0.46 \pm 0.21$ & $0.40 \pm 0.21$ & $0.26 \pm 0.16$ & $0.36 \pm 0.10$ \\
\hline & $2009-2010$ & 62 & $0.27 \pm 0.12$ & $1.52 \pm 0.24$ & $0.45 \pm 0.22$ & $0.68 \pm 0.22$ & $0.72 \pm 0.23$ \\
\hline & 2010-2011 & 58 & $0.22 \pm 0.18$ & $2.63 \pm 0.62$ & $1.23 \pm 0.42$ & $1.88 \pm 0.68$ & $0.83 \pm 0.21$ \\
\hline \multirow{5}{*}{$\mathrm{Cd}$} & $2006-2007$ & 52 & $0.23 \pm 0.11$ & $0.75 \pm 0.40$ & $0.36 \pm 0.26$ & $0.19 \pm 0.12$ & $0.21 \pm 0.15$ \\
\hline & $2007-2008$ & 63 & $0.61 \pm 0.19$ & $1.61 \pm 0.40$ & $0.51 \pm 0.25$ & $0.31 \pm 0.19$ & $0.34 \pm 0.19$ \\
\hline & 2008-2009 & 65 & $0.42 \pm 0.23$ & $1.64 \pm 0.48$ & $0.44 \pm 0.23$ & $0.26 \pm 0.16$ & $0.26 \pm 0.19$ \\
\hline & $2009-2010$ & 62 & $0.28 \pm 0.15$ & $2.72 \pm 1.05$ & $0.45 \pm 0.22$ & $0.32 \pm 0.17$ & $0.36 \pm 0.15$ \\
\hline & 2010-2011 & 58 & $0.71 \pm 0.13$ & $2.47 \pm 0.94$ & $1.44 \pm 0.62$ & $1.20 \pm 0.55$ & $0.41 \pm 0.19$ \\
\hline \multirow{5}{*}{$\mathrm{Cr}$} & $2006-2007$ & 52 & $0.21 \pm 0.12$ & $0.68 \pm 0.41$ & $0.49 \pm 0.26$ & $0.18 \pm 0.13$ & $0.16 \pm 0.14$ \\
\hline & $2007-2008$ & 63 & $0.24 \pm 0.12$ & $1.21 \pm 0.44$ & $0.36 \pm 0.19$ & $0.31 \pm 0.20$ & $0.21 \pm 0.14$ \\
\hline & 2008-2009 & 65 & $0.26 \pm 0.19$ & $1.38 \pm 0.51$ & $0.52 \pm 0.17$ & $0.38 \pm 0.23$ & $0.36 \pm 0.18$ \\
\hline & $2009-2010$ & 62 & $0.35 \pm 0.20$ & $1.49 \pm 0.57$ & $1.51 \pm 0.78$ & $0.51 \pm 0.18$ & $0.31 \pm 0.14$ \\
\hline & 2010-2011 & 58 & $0.24 \pm 0.11$ & $1.14 \pm 0.60$ & $0.41 \pm 0.16$ & $0.42 \pm 0.16$ & $0.41 \pm 0.19$ \\
\hline
\end{tabular}


Table 3. Analysis of variance (ANOVA) in Thunnus tonggol fish from the coast of Karachi

\begin{tabular}{|c|c|c|c|c|c|c|}
\hline Metals & Effect & $\begin{array}{l}\text { Sum of } \\
\text { square }\end{array}$ & $\begin{array}{l}\text { degree of } \\
\text { freedom }\end{array}$ & $\begin{array}{c}\text { Mean of } \\
\text { square }\end{array}$ & $\mathbf{F}$ & $p$ \\
\hline \multirow{6}{*}{$\mathrm{Fe}$} & Organs & 6.5567 & 4 & 1.6397 & 3633.574 & .000 \\
\hline & Year & 63967.280 & 5 & 12793.456 & 2.836 & .015 \\
\hline & Organs * Year & 277665.736 & 16 & 17354.109 & 3.847 & .000 \\
\hline & Error & 8317667.114 & 1400 & 4510.665 & 1.983 & \\
\hline & Total & 1.0288 & 1500 & & & \\
\hline & Corrected Total & 7.7257 & 1499 & & & \\
\hline \multirow{6}{*}{$\mathrm{Mn}$} & Organs & 6031.759 & 4 & 1507.940 & 1413.356 & .000 \\
\hline & Year & 92.881 & 5 & 23.220 & 21.764 & .000 \\
\hline & Organs * Year & 150.582 & 16 & 9.411 & 8.821 & .000 \\
\hline & Error & 1493.690 & 1400 & 1.067 & & \\
\hline & Total & 15456.946 & 1500 & & & \\
\hline & Corrected Total & 8723.561 & 1499 & & & \\
\hline \multirow{6}{*}{$\mathrm{Cu}$} & Organs & 510604.561 & 4 & 127651.140 & 1427.575 & .000 \\
\hline & Year & 156.329 & 5 & 39.082 & .437 & .782 \\
\hline & Organs * Year & 10243.006 & 16 & 640.188 & 7.159 & .000 \\
\hline & Error & 125185.425 & 1400 & 89.418 & & \\
\hline & Total & 1192517.869 & 1500 & & & \\
\hline & Corrected Total & 676540.922 & 1499 & & & \\
\hline \multirow{6}{*}{$\mathrm{Zn}$} & Organs & 49983.109 & 4 & 12495.777 & 658.913 & .000 \\
\hline & Year & 1766.351 & 5 & 441.588 & 23.285 & .000 \\
\hline & Organs * Year & 3508.929 & 16 & 219.308 & 11.564 & .000 \\
\hline & Error & 26834.375 & 1400 & 18.964 & & \\
\hline & Total & 152925.645 & 1500 & & & \\
\hline & Corrected Total & 91269.733 & 1499 & & & \\
\hline \multirow{6}{*}{$\mathrm{Ni}$} & Organs & 58.576 & 4 & 14.644 & 218.844 & .000 \\
\hline & Year & 45.287 & 5 & 11.322 & 169.195 & .000 \\
\hline & Organs * Year & 32.723 & 16 & 2.045 & 30.564 & .000 \\
\hline & Error & 93.682 & 1400 & .067 & & \\
\hline & Total & 681.637 & 1500 & & & \\
\hline & Corrected Total & 255.914 & 1499 & & & \\
\hline \multirow{6}{*}{$\mathrm{Pb}$} & Organs & 15.552 & 4 & 3.888 & 117.965 & .000 \\
\hline & Year & 4.482 & 5 & 1.120 & 33.996 & .000 \\
\hline & Organs * Year & 4.943 & 16 & .309 & 9.373 & .000 \\
\hline & Error & 46.142 & 1400 & .033 & & \\
\hline & Total & 261.296 & & & & \\
\hline & Corrected Total & 77.918 & & & & \\
\hline \multirow{6}{*}{$\mathrm{Cd}$} & Organs & 62.603 & 4 & 15.651 & 132.796 & 000 \\
\hline & Year & 3.266 & 5 & .817 & 6.928 & .000 \\
\hline & Organs * Year & 6.791 & 16 & .424 & 3.601 & .000 \\
\hline & Error & 164.999 & 1400 & .118 & & \\
\hline & Total & 567.067 & 1500 & & & \\
\hline & Corrected Total & 275.872 & 1499 & & & \\
\hline \multirow{6}{*}{$\mathrm{Cr}$} & Organs & 242.802 & 4 & 60.700 & 746.879 & .000 \\
\hline & Year & 10.940 & 5 & 2.735 & 33.651 & .000 \\
\hline & Organs * Year & 8.179 & 16 & .511 & 6.290 & .000 \\
\hline & Error & 113.781 & 1400 & .081 & & \\
\hline & Total & 889.759 & 1500 & & & \\
\hline & Corrected Total & 412.699 & 1499 & & & \\
\hline
\end{tabular}

Note: $*=$ significant at $\mathrm{P}<0.05$. 
Contamination with heavy metals on local, regional and global scales, have been intensively studied in recent years. Due to the fact that metals are persistent and toxic, they tend to accumulate and pose a risk to humans and ecosystems health (Szefer, 2002; Rainbow, 2002). The main reason for this is the increasing metal input to the coastal zone from both rivers and non-point sources (NPS) whichcomes from many diffuse sources. NPS pollution is caused by rainfall or snowmelt moving over and through the ground. As the runoff moves, it picks up and carries away pollutants, finally depositing them into coastal waters, especially in developing countries. Fish have been considered good indicators for heavy metal contamination in aquatic systems because they occupy different trophic levels with different sizes and ages (Burger et al., 2002). Meanwhile, fish are widely consumed in many parts of the world by humans, and polluted fish may endanger human health. The levels of toxic elements in fish are related to age, sex, season and habitat (Kagi et al., 1988). It is also reported that cooking reduces the amount of some metals (Atta et al., 1997). Cd may accumulate in the human body and may induce kidney dysfunction, skeletal damage and reproductive deficiencies. The amount of $\mathrm{Cd}$ in tuna was $0.32,0.35, \mu \mathrm{g} / \mathrm{g}$ in each sample respectively which were higher than those in our samples in southern Iran (Voegborlo et al., 1999; Amundsen et al., 1997). Kojadinovic et al. (2007) suggested that that their muscle impregnation is the result of the accumulation of heavy metals from preys living in other environments than where the fish were caught and which contained high metal levels.

In the present study, Fe was the highest in all tissues of analysed species in the present study, followed by $\mathrm{Cu}$ and $\mathrm{Zn}$. Similar results were found by many researchers (Tepe et al., 2007; Türkmen et al., 2008 and 2009). Metals, such as Fe, $\mathrm{Cu}$ and $\mathrm{Zn}$, are essential metals since they play important roles in biological systems (Türkmen et al., 2009) and the contaminant uptake rate is positively linked to the metabolic rate in marine organisms, it can be supposed that metal accumulation would be high (Kojadinovic et al., 2007) .

Furthermore, the tolerable weekly intakes were estimated by means of references for muscles tissues T. tonggol consumed by people. The average daily fish consumption in Pakistan is $5 \mathrm{~g}$ per person (FAO, 2010). The Joint FAO/WHO Expert Committee on Food Additives established a PTWI for Fe of $5.6 \mathrm{mg} / \mathrm{kg}$ body weight/week which was equivalent to 392 $\mathrm{mg} /$ week for a $70 \mathrm{~kg}$ adult (FAO/WHO, 2010). By using the means of weekly fish consumption in Pakistan of $35 \mathrm{~g}$ per person and the maximum iron levels in muscle tissues of T. tonggol, weekly intake calculated as $1.28 \pm 0.40 \mathrm{mg}(35 \mathrm{~g} \mathrm{x} 36.43 \pm 11.41 \mathrm{mg} / 1000 \mathrm{~g})$ per person for Fe in muscles of fish. The Joint FAO/WHO Expert Committee on Food Additives established a PTWI for $\mathrm{Cu}$ of $3.5 \mathrm{mg} / \mathrm{kg}$ body weight/week which was equivalent to 245 $\mathrm{mg} /$ week for a $70 \mathrm{~kg}$ adult (WHO, 1996; Council of Europe, 2001). By using the means of weekly fish consumption in Pakistan of $35 \mathrm{~g}$ per person and the maximum copper concentrations in muscle tissues of $T$. tonggol, weekly intake calculated as $0.82 \pm 0.40 \mathrm{mg}$ (35 g x $23.35 \pm 11.47 \mathrm{mg} / 1000 \mathrm{~g}$ ) per person for $\mathrm{Cu}$ in muscles of fish. The Joint FAO/WHO Expert Committee on Food Additives established a PTWI for $\mathrm{Zn}$ of $7 \mathrm{mg} / \mathrm{kg}$ body weight/week which was equivalent to $490 \mathrm{mg} /$ week for a $70 \mathrm{~kg}$ adult (WHO, 1996; Council of Europe, 2001). By using the means of weekly fish consumption in Pakistan of $35 \mathrm{~g}$ per person and the maximum $\mathrm{Zn}$ levels in muscle tissues of $T$. tonggol, weekly intake calculated 
as $0.136 \pm 0.078 \mathrm{mg}(35 \mathrm{~g} \mathrm{x} 3.89 \pm 2.23 \mathrm{mg} / 1000 \mathrm{~g})$ per person for zinc in muscles of fish. Fe, $\mathrm{Cu}$ and $\mathrm{Zn}$ are important components of the human body. They are also toxic to most forms of organisms when present in amounts exceeding certain limits Bryan, 1979). Legal thresholds are not available for essential elements in Commission Regulation. However, in the edible muscle tissues of fish the average $\mathrm{Zn}$ concentrations were well below the maximum tolerance levels for human consumption established by compared with the Turkish Food Codex (TGK, 2002) and the Food Safety of Fish Product (MAFF, 1995) $(50 \mu \mathrm{g} / \mathrm{g}$ wet wt.); Georgian Food Safety Rules (2001) and Russian Federation (GAIN, 2002) (40 $\mu \mathrm{g} / \mathrm{g}$ wet wt.). $\mathrm{Cu}$ levels $(23.35 \pm 11.47 \mu \mathrm{g} / \mathrm{g})$ in the edible muscle tissues exceeded the critical limits set by the Turkish Food Codex (TGK, 2002) and the Food Safety of Fish Product (MAFF, 1995) (20 $\mu \mathrm{g} / \mathrm{g}$ wet wt.); Georgian Food Safety Rules (2001) and Russian Federation (GAIN, 2002) $(10 \mu \mathrm{g} / \mathrm{g}$ wet wt.). $\mathrm{Cu}$ is often association with sewage sludge, where it is most likely complexes with a variety of organic compounds. However, the estimated PTWI of Fe, Cu and $\mathrm{Zn}$ in the present study are below the established PTWI. The results of the present study from Table 2 were given as dry wt. and this should be taken into account. On the contrary Mn, Ni and $\mathrm{Cr}$ metals were generally low. $\mathrm{Mn}$ is essential element and an important enzyme cofactor for the activation of a number of enzymes. Mn accumulation was higher in liver followed in gills. It is indicated that fish take Mn from the surrounding water through their gills and accumulated it. Ni is also essential for normal growth and reproduction in human beings, but shows carcinogenic effect when consumed in high amount. $\mathrm{Cr}$ accumulation was higher in kidney of T. tonggol. $\mathrm{Cr}$ is essential element and an important enzyme cofactor which may become toxic when accumulating at a certain level as other essential elements (Underwood, 1977).

$\mathrm{Pb}$ and $\mathrm{Cd}$ belong to the group of non-essential and toxic metals and they have no known function in biochemical processes and are accumulated in multiple organs (Phillips, 1977). The maximum $\mathrm{Pb}$ concentrations in all tissues except edible muscle were considerably higher than the maximum level $(0.30 \mu \mathrm{g} / \mathrm{g}$ wet wt.) set by EC (Commission Regulation) (Anonymous, 2006) and Turkish Food Codex (TGK, 2008). Pb is a heavy metal that occurs in nature mainly lead sulphide and a powerful neurotoxin even in trace quantities, it is currently used in batteries, alloys, shot, paints and gasoline (The Earth Report 3, 1992). This metal is extremely insoluble and is readily absorbed by organic matter, especially under reducing conditions and is highest in the immediate vicinity of industrial activity and river inputs (GESAMP, 1990). The Joint FAO/WHO Expert Committee on Food Additives established a $\mathrm{PTWI}$ for $\mathrm{Pb}$ of $0.025 \mathrm{mg} / \mathrm{kg}$ body weight/week which was equivalent to $1.725 \mathrm{mg} / \mathrm{week}$ for a $70 \mathrm{~kg}$ adult (WHO, 2000; Council of Europe, 2001; FAO/WHO, 2010). By using the means of weekly fish consumption in Pakistan of $35 \mathrm{~g}$ per person and the maximum $\mathrm{Pb}$ levels in muscle tissues of $T$. tonggol, weekly intake calculated ranged from $0.009 \pm 0.004 \mathrm{mg}(35 \mathrm{~g} \mathrm{x}$ $0.27 \pm 0.12 \mathrm{mg} / 1000 \mathrm{~g}$ ) per person for $\mathrm{Pb}$ in muscles of fish. In terms of $\mathrm{Pb}$ concentrations in the edible muscle tissues of T. tonggol was lower than permissible limits and seems to be appropriate for human health. It is important to note that the liver and visceral of T. tonggol from Karachi Fish Harbour should be removed and well washed before consumption. Similarly, the maximum Cd concentrations in all tissues were considerably higher than the maximum level (0.05 $\mu \mathrm{g} / \mathrm{g}$ wet wt.) set by EC (Commission Regulation) (Anonymous, 2006) 
and Turkish Food Codex (TGK, 2008). The Joint FAO/WHO Expert Committee on Food Additives established a PTWI for $\mathrm{Cd}$ of $0.007 \mathrm{mg} / \mathrm{kg}$ body weight/week which was equivalent to $0.49 \mathrm{mg} /$ week for a $70 \mathrm{~kg}$ adult (WHO, 1989 and 2004; Council of Europe, 2001; FAO/WHO, 2010). By using the means of weekly fish consumption in Pakistan of $35 \mathrm{~g}$ per person and the maximum $\mathrm{Cd}$ levels in muscle tissues of $T$. tonggol, weekly intake calculated ranged from $0.025 \pm 0.005 \mathrm{mg}(35 \mathrm{~g} \mathrm{x} 0.71 \pm 0.13 \mathrm{mg} / 1000 \mathrm{~g})$ per person for $\mathrm{Cd}$ in muscles of fish. As regards $\mathrm{Cd}$ concentrations in muscle tissues of $T$. tonggol, the estimated PTWI in the present study is above the established PTWI. Cd is naturally present in phosphate fertilizers and is discharged to the environment when they refined (The Earth Report 3, 1992). The available data suggest that $\mathrm{Cd}$ in the open ocean is derived, for the most part, from natural sources such as rock weathering or sea-bed eruptions (GESAMP, 1990). Cd is used in metal plating in certain plastics as pigment and in some rechargeable batteries and chronic Cd poisoning causes damage to the kidneys and heart (The Earth Report 3, 1992). Fish is one of the most important food sources, and thus, intake of metals when consuming fish, especially toxic metals if one of great concern for human health. As a consequence of heavy metal toxicity and of the serious contamination of food that occurs from time to time during commercial handling and processing, most countries monitor the levels of toxic elements in foods. However, the potential hazards of metals transferred to humans are probably dependent on amount of muscles consumed by an individual.

\section{Conclusion}

The values of all metals except $\mathrm{Cd}$ in muscles of analysed fish in the present study stayed below the established limit values. It is suggesting that the concentration of $\mathrm{Cd}$ in muscle tissues of T. tonggol from Karachi Fish Harbour pose to health hazards to the consumers. Therefore it is concluded that the regular monitoring of commercial fish of marine coastal areas is essentially required.

\section{Acknowledgement}

Suggestions from anonymous reviewers are greatly appreciated.

\section{References}

Akif, M., Khan, A. R., Sok, K., Min, K. S., Hussain, Z., \& Maal-Abrar, M. (2002). Textile effluents and their contribution towards aquatic pollution in the Kabul River (Pakistan). Journal of Chemical Society of Pakistan, 24(2), 106-111.

Amundsen, P. A., Staldvik, F. J., Lukin, A. A., Kashulin, N. A., Popova, O. A., \& Reshetnikov, Y. K. (1997). Heavy metal contamination in freshwater fish from the border region between Norway and Russia. Science of the Total Environment, 201(3), 211-224. http://dx.doi.org/10.1016/S0048-9697(97)84058-2

Anonymous. (2006). Official Journal of the European Union. Setting maximum levels for certain contaminants in foodstuffs. Commission Regulation (EC) No 1881/2006: 364, 5-24.

Atta, M. B., El-Sebaie, L. A., Noaman, M. A., \& Kassab, H. E. (1997). The effect of cooking on the content of heavy metals in fish (Tilapia nilotica). Food Chemistry, 58, 1-4. http://dx.doi.org/10.1016/0308-8146(95)00205-7 
Bat, L., Sezgin., M., Gökkurt Baki, O., Üstün, F., \& Şahin, F. (2013). Determination of heavy metals in some commercial fish from the Black Sea coast of Turkey. Walailak $J$ Sci \& Tech., 10(6), 581-589.

Bernhard, M. (1976). Manual of Methods in the Aquatic Environment Research. FAO Fisheries Technical Paper FIRI/T no.158, Food and Agriculture Organisation, Rome.

Bryan, G. W. (1979). Bioaccumulation of marine pollutants. Philos. Trans. R. Soc. Lond. B. Bioi. Sci., 286, 483-505. http://dx.doi.org/10.1098/rstb.1979.0042

Burger, J., Gaines, K. F., Boring, C. S., Stephens, W. L., Snodgrass, J., Dixon, C., McMahon, M., Shukla, S., Shukla, T., \& Gochfeld, M. (2002). Metal levels in fish from the Savannah River potential hazards to fish and other receptors. Environmental Research, 89, 85-97. http://dx.doi.org/10.1006/enrs.2002.4330

Connell, J. J. (1984). Control of fish quality. London: Fishing News Books Ltd.

Council of Europe. (2001). Council of Europe's policy statements concerning materials and articles intended to come into contact with foodstuffs. Policy Statement concerning materials and alloys. Technical Document. Guidelines on metals and alloys used as food contact materials. (09.03.2001), 67 pp., Strasbourg.

Enomoto, N., \& Uchida, Y. (1973). Cadmium and other heavy metals contents in marine products from Ariak sea in canned goods on the market. Saga daigaku Nogaku Inho, 69-75[cited in Chem. Abstr., 18(1974) 2506].

FAO. (2010). The food consumption refers to the amount of food available for human consumption as estimated by the FAO Food Balance Sheets.

FAO/WHO. (2010). Summary report of the seventy-third meeting of JECFA. Joint FAO/WHO Expert Committee on Food Additives. Geneva, 17 pages.

GAIN (Global Agriculture Information Network) Report. (2002). Russian Federation Sanitary/ Phytosanitary/ Food Safety Russian Sanitary Rules and Norms. GAIN Report, RS2010. SanPiN-96. USDA Foreign Agricultural Service. Gossanepidnadzor Department of the Ministry of Public Health Care of Russia.

Georgian Food Safety Rules. (2001). Fish, other river/sea products and products made from them. SanPiN-2.3.2.560-96. The Minister's Decree 16/08/2001 N301/n for Health, Labour and Social Affairs.

GESAMP. (1990). The state of the marine environment. Blackwell Scientific Publications, Oxford, 146 pages.

Gutierrez, M., Stablier, R. E., \& Arias, A. M. (1978). Accumulation y effectos histpatologicos del $\mathrm{Cd}$ yel $\mathrm{Hg}$ en el pez sapo (Halobatrachus didactylus). Investigaciones Pesqueras, 42, 141-154.

Kagi, J. H. R., \& Schaffer, A. (1988). Biochemistry of metallothionein. Biochemistry, 27(23), 8509-8515. http://dx.doi.org/10.1021/bi00423a001

Kojadinovic, J., Potier, M., Le Corre, M., Cosson, R. P., \& Bustamante, P. (2007). Bioaccumulation of trace elements in pelagic fish from the Western Indian Ocean Environmental Pollution, 146(2), 548-566. 
MAFF. (1995). Monitoring and surveillance of non-radioactive contaminants in the aquatic environment and activities regulating the disposal of wastes at sea, 1993, Directorate of Fisheries research, Lowestoft, Aquatic Environment Monitoring Report, No.44.

Nieboer, E., \& Richardson, D. H. S. (1980). The replacement of the nondescript term 'heavy metals' by a biologically and chemically significant classification of metal ions. Environ. Pollut., 1(B), 3-26.

Pérez Cid, B., Boia, C., Pombo, L., \& Rebelo, E. (2001). Determination of trace metals in fish species of the Ria de Aveiro (Portugal) by electro thermal atomic absorption $\begin{array}{llll}\text { spectrometry. } & \text { Food } & \text { Chemistry, } & \text { 75(1), }\end{array}$ http://dx.doi.org/10.1016/S0308-8146(01)00184-4

Phillips, D. J. H. (1977). The use of biological indicator organisms to monitor trace metal pollution in marine and estuarine environments. A review. Environ. Pollut., 13, 281-317. http://dx.doi.org/10.1016/0013-9327(77)90047-7

Rainbow, P. S. (2002). Trace metal concentrations in aquatic invertebrates: why and so what? Environ. Pollut., 120, 497-507. http://dx.doi.org/10.1016/S0269-7491(02)00238-5

Schmitt, C. J., \& Brumbaugh, W. G. (1990). National contamination biomonitoring program:Concentrations of arsenic, cadmium, copper, lead, mercury, selenium and zinc in US fresh water fish, 1976-1984. Archives of Environmental Contamination and Toxicology, 19, 731-747. http://dx.doi.org/10.1007/BF01183991

Schroeder, H. A. (1965). Cadmium as a factor in hypertension. Journal of Chronic Diseases, 18(7), 647-678. http://dx.doi.org/10.1016/0021-9681(65)90066-4

Szefer, P. (2002). Metals, Metalloids and Radionuclides in the Baltic Sea Ecosystem. Elsevier Science, Amsterdam.

Tarra-Wahlberg, N. H., Flachierm, A., Lane, S. N., \& Sangfors, O. (2001). Environmental impacts and metal exposure of aquatic ecosystems in rivers contaminated by small scale gold mining: The Puyango River Basin,Sourthen Ecuador. Science of the Total Environment, 278(1-3), 239-261. http://dx.doi.org/10.1016/S0048-9697(01)00655-6

Tepe, Y., Türkmen, M., \& Türkmen, A. (2007). Assessment of heavy metals in two commercial fish species of four Turkish seas. Environmental Monitoring and Assessment, 146, 277-284. http://dx.doi.org/10.1007/s10661-007-0079-3

Topping, G. (1973). Heavy metals in fish from Scottish waters. Aquaculture, 11, 373-377.

The Earth Report 3. (1992). An A-Z Guide to environmental issues. (General Eds.) Goldsmith, E. and Hildyard, N. London, 175 p.

TGK. (2002). Official Gazette of Republic of Turkey. Notifications about determination of the maximum levels for certain contaminants in foodstuffs of Turkish Food Codex (in Turkish). (Notification No: 2002/63), Issue: 24885.

TGK. (2008). Official Gazette of Republic of Turkey. Notifications about maximum levels for certain contaminants in foodstuffs (in Turkish). Turkish Food Codex No 2008 / 26, Issue: 26879. 


\section{Macrothink}

Aquatic Science and Technology

ISSN 2168-9148 2015, Vol. 3, No. 1

Türkmen, M., Türkmen, A., \& Tepe, Y. (2008). Metal contaminations in five fish species from Black, Marmara, Aegean and Mediterranean Seas, Turkey. J. Chil. Chem. Soc., 53(1), 1435-1439. http://dx.doi.org/10.4067/S0717-97072008000100021

Türkmen, M., Türkmen, A., Tepe, Y., Töre, Y., \& Ateş, A. (2009). Determination of metals in fish species from Aegean and Mediterranean seas. Food Chemistry, 113, 233-237. http://dx.doi.org/10.1016/j.foodchem.2008.06.071

Underwood, E. J. (1977). Trace elements in human and animal nutrition (4th ed.). New York: Academic Press.

Voegborlo, R. B., El-Methnani, A. M., \& Abedin, M. Z. (1999). Mercury, cadmium and lead content of canned tuna fish. Food Chemistry, 67, 341-345. http://dx.doi.org/10.1016/S0308-8146(98)00008-9

WHO. (1989). Evaluation of certain food additives and contaminants. Report of the Thirty-Third of the Joint FAO/WHO Expert Committee on Food Additives. Technical Report Series No. 776. Geneva.

WHO. (1996). Trace elements in human nutrition and health. ISBN 9241561734 (NLM Classification: QU 130). Geneva.

WHO. (2000). Evaluation of certain food additives and contaminants. Report of the Fifty-Third of the Joint FAO/WHO Expert Committee on Food Additives. Technical Report Series No. 896. Geneva.

WHO. (2004). Evaluation of certain food additives and contaminants. Report of the Sixty-First of the Joint FAO/WHO Expert Committee on Food Additives. Technical Report Series No. 922. Geneva.

Zar, J. H. (1984). Biostatistical analysis (2nd ed.). New Jersey: Prentice Hall, Int.

\section{Copyright Disclaimer}

Copyright for this article is retained by the author(s), with first publication rights granted to the journal.

This is an open-access article distributed under the terms and conditions of the Creative Commons Attribution license (http://creativecommons.org/licenses/by/3.0/). 